\title{
Student Loan Debt: Can Parental College Savings Help?
}

\author{
William Elliott, Melinda Lewis, Michal Grinstein-Weiss, and IlSung Nam
}

Postsecondary education costs in the United States today are rising with an increasing shift from societal responsibility to individual burden, thereby driving greater student borrowing. Evidence suggests that (i) such student debt may have undesirable educational effects and potentially jeopardize household balance sheets and (ii) student loans may better support educational attainment and economic mobility if accompanied by other, non-repayable financial awards. However, given declines in need-based aid and falling state support for postsecondary costs, policymakers and parents alike have failed to produce a compelling complement to debt-dependent financial aid that is capable of improving outcomes and forestalling assumption of ever-increasing student debt for a majority of U.S. households. This article, which relies on longitudinal data from the Educational Longitudinal Study, finds parental college savings may be an important protective factor in reducing debt assumption. However, several other factors increase the likelihood students will borrow: perceiving financial aid as necessary for college attendance, expecting to borrow to finance higher education, having moderate income, and attending a for-profit college. After controlling for student and school variables, the authors find that parental college savings increase a student's chance of accumulating lower debt (less than \$2,000) compared with students lacking such savings. Policy innovations to increase parental college savingssuch as children's savings accounts-could be an important piece of the response to the student debt problem in the United States. (JEL I2, I22, I24)

Federal Reserve Bank of St. Louis Review, Fourth Quarter 2014, 96(4), pp. 331-57.

\footnotetext{
William Elliott is an associate professor and Melinda Lewis is an associate professor of practice in the School of Social Welfare at the University of Kansas. Michal Grinstein-Weiss is an associate professor in the School of Social Work at Washington University in St. Louis. IISung Nam is a research professor at the Hallym University Institute of Aging. This paper was prepared for the symposium "The Balance Sheets of Younger Americans: Is the American Dream at Risk?" presented May 8 and 9, 2014, by the Center for Household Financial Stability and the Research Division at the Federal Reserve Bank of St. Louis and the Center for Social Development at Washington University in St. Louis.

() 2014, The Federal Reserve Bank of St. Louis. The views expressed in this article are those of the author(s) and do not necessarily reflect the views of the Federal Reserve System, the Board of Governors, or the regional Federal Reserve Banks. Articles may be reprinted, reproduced, published, distributed, displayed, and transmitted in their entirety if copyright notice, author name(s), and full citation are included. Abstracts, synopses, and other derivative works may be made only with prior written permission of the Federal Reserve Bank of St. Louis.
} 
cost shifts more than absolute cost increases, the potential sticker shock for prospective college students and their families is the same, and the effects can be seen in educational attainment, particularly for low-income students and students of color, who may be most sensitive to price. Researchers find that increasing college costs have a negative impact on college enrollment decisions (Heller, 1997; Leslie and Brinkman, 1988; McPherson and Schapiro, 1999). McPherson and Schapiro (1999) estimate that a $\$ 150$ net cost increase (in 1993-94 dollars) results in a 1.6-percentage-point reduction in enrollment among low-income students. Against the backdrop of rising prices and a persistently elevated unemployment rate, more Americans-from pundits to parents-are questioning the value of a college degree (see Azziz, 2014), even while evidence clearly points to higher education as the primary path to economic mobility and prosperity (see Urahn et al., 2012). Frustrated by the collision of rising prices and declining wages (in inflation-adjusted dollars) (College Board, 2012a), Americans are seeking new ladders of human capital accumulation and related economic advancement. Still, the current public policy debate is limited mainly to tinkering around the edges of a primarily debt-dependent financial aid system. The debate includes discussion of income-based college loan repayment and other modifications to the cost and terms of borrowing, even while evidence suggests a need to rethink the true cost of student loans and to consider alternative approaches to higher education financing.

\section{SHIFTING THE BURDEN OF COLLEGE COSTS FROM SOCIETY TO STUDENTS}

Since the late 1970s, the federal government has increasingly attempted to promote equal access to higher education by adopting policies to make college loans accessible to more students (Heller, 2008). Most recently, the Health Care and Education Reconciliation Act (2010) routed all federal loans through the Direct Loan Program, making it easier for students and families to borrow directly from the U.S. Department of Education. At the same time, costs are being pushed upward by disinvestment in direct public support for institutions (U.S. Department of Education, 2013).

State appropriations for colleges sank by 7.6 percent in 2011-12, its largest decline in at least a half century (Center for the Study of Education Policy, 2013). As a result, 29 states allocated less money to higher education in 2011-12 than they did in 2006-7 (Center for the Study of Education Policy, 2013). Historically, public investment in higher education tends to be cyclical, with state and local appropriations for public institutions, in particular, declining during economic downturns (Desrochers, Lenihan, and Wellman, 2010).

Today, many analysts fear both cyclical declines and structural adjustments are at play as higher education is increasingly framed as an individual benefit instead of a public good (Hiltonsmith, 2013). This change in viewpoint has resulted in a "pattern of cost shifting to student tuition revenues" (Desrochers, Lenihan, and Wellman, 2010, p. 5). The College Board reported in 2013 that the net price of in-state tuition increased to $\$ 3,120$ after all aid was considered, signaling that even this last refuge of affordability is now a cost burden to many of the poorest American students. All American families may feel the effects of this cost shift; but to 
at least some extent, those less able to shoulder their share-low-income households-will pay the highest price (Elliott and Friedline, 2012).

Higher college prices and declining real family incomes are only two parts of the equation adding to the financial squeeze felt by students approaching enrollment. Declines in the purchasing power of need-based financial aid also are significant. Just 10 years ago, the maximum Pell grant amount covered 98 percent of the average tuition and fees at public four-year institutions; in the 2012-13 academic year, this figure dropped to 64 percent (College Board, 2013). Significantly, this difference reflects not only recessionary budget cuts but also longer-term shifts in financial assistance from need-based aid to merit-based aid (Woo and Choy, 2011). Need-based aid is determined solely by the assets and income (i.e., financial need) of prospective students and their families. Factors such as test scores have no bearing on the aid decision. Merit-based aid-most commonly, scholarships-often is awarded based on test scores. Students with little financial need have the same entitlement to merit-based aid as students with high levels of financial need. Woo and Choy (2011) find that the proportion of undergraduates receiving merit-based aid rose from 6 percent in 1995-96 to 14 percent in 2007-08. Furthermore, research suggests that merit-based aid is awarded disproportionately to students from higher-income families (Woo and Choy, 2011), in large part because of the advantages they enjoy in educational environments and support in attainment. This shift has done little to improve college enrollment rates among low-income and minority students (Marin, 2002).

The resulting perfect storm of rising college prices, eroding real incomes, and declining purchasing power of financial aid creates "unmet need," the hole that must be filled with student loans even beyond the point of reasonable affordability. Unmet need can be a barrier to academic success and upward mobility, forcing students to work longer hours, scale back enrollment, or adjust degree completion plans (Castleman and Long, 2013). Sometimes unmet need may derail higher education entirely; a 2009 study found that 69 percent of students who left school without a degree or certificate did not receive scholarships or financial aid (Johnson and Rochkind, 2013). Of course, these adverse educational effects are not evenly distributed; instead, they fall most heavily on low-income and otherwise disadvantaged students most in need of the mobility and promise a college education can provide.

As a result of these changes, Elliott and Friedline (2012) find that students might carry a larger proportion of the college cost burden. Students may use a patchwork approach to financing college costs. They may have to use parental or their own savings and job earnings to lower costs. They may also need to consider student loans or federal work-study programs. They also find that the college cost burden might vary by race, income level (the focus of this article), and length of college program. Elliott and Friedline (2012) find that the college cost burden for four-year college enrollment is lowest among the lowest-income group but highest among the middle-income group. However, they find evidence to suggest that parental college savings may help lower the debt burden on students.

\section{Growing Amounts of Student Debt}

Americans consider student loans to be investments that support long-term achievement (Cunningham and Santiago, 2008). Indeed, to the extent that higher education correlates to 
higher lifetime earnings (Carnevale, Rose, and Cheah, 2011), this accounting of student loans as a ratio of monthly payments to increased earning potential is reinforced. However, college borrowing has real costs for students, who increasingly leave college with debt. During the 2011-12 school year, federal loans provided 37 percent of all undergraduate financial aid received ( $\$ 70.8$ billion) (College Board, 2012b). The next-highest sources were federal Pell grants (19 percent) and institutional grants (18 percent). The percentage of undergraduate students who obtained federal loans increased from 23 percent in 2001-02 to 35 percent in 2011-12. In 2010-11, nearly 57 percent of students at public four-year colleges graduated with some debt (College Board, 2012b). On average, students who attended public four-year colleges borrowed $\$ 23,800$. Total borrowing for college hit $\$ 113.4$ billion for the 2011-12 school year, up 24 percent from 2007 (College Board, 2012b). Of course, this indebtedness persists after college completion; Fry (2012) found that 40 percent of all households headed by individuals younger than 35 years of age have outstanding student debt.

\section{Too Much Debt May Have Undesired Educational Effects}

As a policy mechanism, student loans are designed to ensure that more students have access to college by providing additional funds at the time of enrollment. However, research suggests that after a certain level, student loans may not produce the desired effect of increased enrollment and graduation rates (Dwyer, McCloud, and Hodson, 2012, and Heller, 2008). If this premise is true, simply continuing to increase the amount of loans available to students may not produce the desired effects. Instead, to preserve the role of higher education as an arbiter of equity and a tool for economic mobility (Elliott and Lewis, 2013), other complementary financial aid policies may be necessary.

Heller (2008) concludes after an extensive literature review that very little evidence suggests that loans improve outcomes. Similarly, Cofer and Somers (2001) suggest that larger loan amounts are counterproductive and fail to meet the goal of greater college accessibility, whereas smaller loan amounts might have positive effects. Dwyer, McCloud, and Hodson (2012) find that debt below $\$ 10,000$ has a positive relationship with college completion, while debt above $\$ 10,000$ has a negative relationship with college completion for the bottom 75 percent of the income distribution in their study. Other researchers find evidence that loan debt may have a more negative impact on college persistence during the first year than in subsequent years (Dowd and Coury, 2006, and Kim, 2007).

Further, prior research suggests that student loans may be a more effective strategy for middle- and high-income students because low-income students are averse to borrowing (Campaigne and Hossler, 1998, and Paulsen and St. John, 2002). Similar findings exist with regard to race: Perna (2000) finds that student loans have a negative effect for black students on enrollment in a four-year college, which she attributes in part to an aversion to borrowing. This aversion suggests cause for concern with the indiscriminate preference of borrowing over other forms of college financing within the financial aid system, even for students for whom loans may be problematic.

Interestingly, evidence suggests that loans plus grants might be a more effective strategy than loans alone. For example, Hu and St. John (2001) examine different types of financial 
aid among different racial groups: They find that, when combined with grants, loans have a more positive effect on persistence than loans only. This led Heller (2008) to conclude that "If grant aid were proportionally higher, then loans might provide more of a positive impact on college participation" (p. 49). However, with the shift toward merit-based aid for determining eligibility for grants and scholarships, some researchers suggest that grants increasingly benefit middle- and upper-income students (Woo and Choy, 2011) instead of low-income students for whom large debt assumption may be particularly forbidding.

\section{Student Debt, Equity, and the Macroeconomy}

While the understanding of the effects of debt on educational outcomes is still evolving, correlational evidence suggests the full accounting of the cost of student loans must include not only the more direct effects on educational attainment but also how dependence on student borrowing may jeopardize the balance sheets of American households (Elliott and Lewis, 2013). This, of course, is a circular relationship: Compromised family balance sheets, eroded by the pressures of the Great Recession, massive loss of housing value, and reductions in net worth wrought by elevated unemployment and constrained wages, also drive dependence on student loans (Chopra, 2013). While wealthy households demonstrate considerable ability to use debt to their advantage in pursuit of greater asset accumulation, low-income students are often forced to rely on borrowing as the sole mechanism of college finance. Even while they are building human capital, these students may then find themselves increasingly unable to accumulate financial assets in the face of overwhelming liabilities. These twin blows to household balance sheets have significant effects on individual well-being by reducing access to human capital development, particularly college education (Zhan and Sherraden, 2011). These combined factors lead to (i) constraining economic mobility (Cramer et al., 2009), as assets are usually needed to accumulate additional wealth and gain access to ladders of economic opportunity (Elliott and Lewis, 2014) and (ii) engendering financial insecurity, as households lack reserves with which to withstand future downturns (Boshara and Emmons, 2013). In the aggregate, these effects point to some of the ways in which student debt may influence macroeconomic health, even at levels short of the foretold "crisis." If reductions in household wealth may be at least partly to blame for the rather anemic recovery following the recession, there is certainly reason to believe that the U.S. economy cannot easily withstand significant erosion of household balance sheet health.

\section{SAVING AND THE POTENTIAL TO EXPAND THE CAPACITY OF STUDENT LOANS}

The growing belief among policymakers is that the individual-who benefits most from attending college-should bear more personal responsibility for college costs. Thus, there might be very little political will to continue increasing the number of scholarships and grants available to students. Given this belief, there may be a need for a financial aid innovation that not only aligns with the notion of individual responsibility but also supplements student loans. 
Asset accumulation strategies, such as children's savings accounts (CSAs), might be just such an innovation within the financial aid system.

CSAs might serve as a policy vehicle for allocating intellectual and material resources to low- and moderate-income children. Unlike basic savings accounts, CSAs leverage investments by individuals, families, and sometimes third parties (e.g., initial deposits, incentives, matches). CSAs align with the ideals of personal responsibility because they require students and their families to help pay for college by saving. A growing body of literature (Elliott, Song, and Nam, 2013) supports the potential for positive educational outcomes from asset accumulation, which has led to CSA program innovation and momentum around the country. However, the political window created by the perception of a student loan crisis and the growing discontent with the U.S. college financing system may be the path by which CSAs garner sufficient traction to grow to scale.

Researchers who study CSAs suggest the accounts have the potential for both direct effects (e.g., reducing the price of college by providing students with money to pay for college) and indirect effects (e.g., improving engagement in school prior to college by making college appear within reach, thereby reducing the educational attainment gap) (Elliott et al., 2011). Researchers also find that saving is associated with college enrollment (Elliott and Beverly, 2011a), college persistence (Elliott and Beverly, 2011b), and college graduation (Elliott, 2013).

While some evidence suggests that assets-such as net worth and savings accounts-do have positive relationships with college enrollment and graduation (see Elliott, Destin, and Friedline, 2011), there is little information about whether CSAs can help reduce student debt. In this study, we focus on the role of parents' savings for their children's college education and their potential to reduce the amount of debt students are forced to assume to attend college. We focus on savings accounts because they most closely resemble CSAs, which can be thought of as savings accounts for children. Because CSAs allow and encourage not only children but also parents and others to save in the accounts, Loke and Sherraden (2009) suggest they might have a "multiplier effect by engaging the larger family in the asset-accumulation process" (p. 119).

\section{RESEARCH QUESTIONS}

In this study we address the following questions:

- Are students whose parents had savings to help pay for their four-year college degree less likely to have any student loan debt than students whose parents did not have savings to help pay for their four-year college degree?

- Do students whose parents had savings to help pay for their four-year college degree have less college debt than students whose parents did not have savings to help pay for their college?

- Are parental savings to help pay for a four-year college degree associated with a lower threshold of student loan debt? 


\section{METHODS}

\section{Dataset}

This study uses longitudinal data from the Educational Longitudinal Survey (ELS) available to the public through the National Center for Education Statistics (NCES). The survey began in 2002 when students were in 10th grade; follow-up waves took place in 2004, 2006, and 2012. The survey, designed to follow students as they progressed through high school and transitioned to postsecondary education or the labor market, is an ideal dataset to test whether early experiences or resources predicted later outcomes.

The ELS aimed to present a holistic picture of student achievement by gathering information from multiple sources. Students, their parents, teachers, school librarians, and principals provided information regarding students' average grades, math achievement, educational expectations, school resources and curriculum, teacher experience, student and parent work/ employment, and students' enrollment in college.

\section{Study Sample}

The final sample of this study is restricted to students who were in the 2002 10th-grade cohort and the 2012 ELS samples (i.e., those who answered the follow-up questionnaires). We also restricted the sample to graduates of four-year colleges who did not then attend graduate school. The amounts of college debt differ if students graduated from a four-year college or if they then attended graduate school (Miller, 2014). After these restrictions were applied, the full sample included 2,992 students.

\section{Student Variables}

Dependent variables in this study are from the 2012 wave, and independent variables are from the 2002, 2004, 2006, and 2012 waves depending on availability.

Student Race/Ethnicity. The variable representing race included seven categories in the ELS. Students whose race was listed as Native American, Alaska Native, or more than one race were not included in this analysis due to small sample sizes, and the Hispanic and Latino categories were combined. Four categories were included in the final analysis: $0=$ white, $1=$ black, 2 = Latino/Hispanic, and $3=$ Asian (downloaded from 2002 data).

Gender. A student's gender is coded as: $0=$ female, $1=$ male (downloaded from 2002 data).

Students' High School GPA. A student's grade point average (GPA) is a categorical variable that averages grades for all coursework in 9th through 12th grades. The ELS has seven GPA categories: $0=0.00-1.00,1=1.01-1.50,2=1.51-2.00,3=2.01-2.50,4=2.51-3.00,5=3.01-3.50$, and $6=3.51-4.00$. We collapsed categories 0 through 2 into one category due to small frequencies $(36,156$, and 782 , respectively). To convert the categories into letter grades, a commonly used grade scale is GPA category $0=\mathrm{F}, 1=\mathrm{D}, 2-3=\mathrm{C}, 4-5=\mathrm{B}$, and $6=\mathrm{A}$ (downloaded from 2002 data).

Students' Perception of College Costs. Students were asked how important they considered low costs (e.g., of tuition, books, room and board) in choosing a school. Responses were coded as follows: $0=$ not very important, 1 = very important (downloaded from 2002 data). 
Students' Perception of Financial Aid. Students were asked how important they considered the availability of financial aid in choosing a school. Responses were dichotomized as follows: 1 = very important, 0 = not very important (downloaded from 2002 data).

Students' Perception of College Choice Basis. Students were asked if they thought they would have to choose a college based on cost. Responses were as follows: $0=$ no, $1=$ yes (downloaded from 2002 data).

Amount Student Expected To Borrow. Students were asked the amount they expected in undergraduate student loans in the future. The amount expected to borrow is a categorical variable in the ELS: $1=\$ 0-1,999 ; 2=\$ 2,000-3,999 ; 3=\$ 4,000-5,999 ; 4=\$ 6,000-7,999$; $5=\$ 8,000-9,999 ; 6=\$ 10,000-14,999 ; 7=\$ 15,000-19,999 ; 8=\$ 20,000$ or more. In this study, the expected student loan amount was collapsed into a three-level variable as follows: $0=\$ 0$ $\$ 9,999 ; 1=\$ 10,000-\$ 19,999 ; 2=\$ 20,000$ or more (downloaded from 2002 data).

\section{Parental/Household Variables}

Household Income. The ELS included 13 distinct household income levels. For this study, the levels of household income were combined into four levels: $0=$ low income $(\$ 0-\$ 35,000)$; $1=$ moderate income $(\$ 35,001-\$ 75,000) ; 2=$ middle income $(\$ 75,001-\$ 100,000)$; and $3=$ high income ( $\$ 100,001$ or higher). These levels were chosen, in part, to have relatively equal cases in each category while maintaining important distinctions between income groups (downloaded from 2002 data).

Parental Education Level. Parental education level is equivalent to the highest educational level achieved by the head of household and includes eight distinct levels in the ELS. The eight levels were collapsed into three for the final analysis: $0=$ high school diploma or less, $1=$ some college, 2 = four-year college degree or higher (downloaded from 2002 data).

Number of Siblings. The number of a student's siblings was a continuous variable that ranged from 0 to 7 . We collapsed families with 4 to 7 siblings into the same category because of small frequencies with a new range of 0 to 4 as follows: $0=0$ siblings, $1=1$ sibling, $2=2$ siblings, 3 = 3 siblings, $4=4$ or more siblings (downloaded from 2002 data).

\section{Secondary School Variables}

College Counseling. This is a dichotomous variable that indicates whether the student had visited the high school's counselor for college entrance information: $0=$ no, $1=$ yes (downloaded from 2004 data).

Percentage of Students Who Attended a Four-Year College. The percentage of 2003 high school graduates who attended a four-year college (i.e., this is the percentage from a student's high school when in the 10th grade) was categorized as follows: $1=$ none, $2=1$-10 percent, $3=11-24$ percent, $4=25-49$ percent, $5=50-74$ percent, $6=75-100$ percent. Categories 1 through 4 were collapsed into one category to better balance the sample and because we felt 50 percent or more would represent a high level of students attending four-year colleges (downloaded from 2004 data). 


\section{University Variables}

Application for Financial Aid. Students were asked if they applied for financial aid, which resulted in a dichotomous variable: $0=$ no, 1 = yes (downloaded from 2006 data).

Out-of-State Residency. This is a dichotomous variable indicating whether the student attended college in the state where he or she lived: $0=$ no, $1=$ yes (downloaded from 2006 data).

Dependent Status. This is a dichotomous variable indicating whether students lived with their parents in 2006: $0=$ no, $1=$ yes (downloaded from 2006 data).

College Selectivity. The following categories comprise the college selectivity variable: 1 = public, four-year; 2 = private, not-for-profit, four-year; 3 = private, for-profit, four-year; 4 = public, two-year; 5 = private, not-for-profit, two-year; 6 = private, for-profit, two-year; $7=$ public, less than two-year; $8=$ private, not-for-profit, less than two-year; $9=$ private, forprofit, less than two-year college. Due to sample restrictions-including only students who graduated from a four-year college-these nine categories were recoded as a three-level variable with the following categories: $0=$ public, four-year; 1 = private, four-year; 2 = private, forprofit, four-year (downloaded from 2006 data).

\section{Variable of Interest}

Parental Savings for College. The variable of interest came from a survey question asking parents whether they were financially preparing to pay for their children to attend college by starting a savings account: $0=$ no, 1 = yes (downloaded from 2002 data).

\section{Outcome Variables}

Student Debt. The student debt outcome variable is a dichotomous variable (i.e., has student loan debt/does not have student loan debt) (downloaded from 2012 data).

Amount of Student Loan Debt. The outcome variable, amount of student loan debt, was drawn from the 2012 wave and was a continuous variable (downloaded from 2012 data).

Student Debt Threshold. We also created a three-level debt variable: $0=\$ 0-\$ 1,999$; $1=\$ 2,000-\$ 19,999$; and $2=\$ 20,000$ or more. These categories were chosen based on the distribution of the data (downloaded from 2012 data).

\section{ANALYSIS PLAN}

We used two steps-with no problems of multicollinearity - to produce and analyze results for predictors of student college loan debt. In the first step, we conducted propensity score analyses for parents with a savings account for their child's college education (i.e., treated cases) and parents without a savings account for their child's college education (i.e., non-treated cases). We used two propensity score analyses (i.e., one-to-one matching and propensity score weighting) to cross-validate the results from the two models that adjust selection bias given the observed covariates. In the second step, we conducted multilevel modeling given that the children in this study are nested within schools. 


\section{Propensity Score Analyses}

A propensity score matching was performed on whether or not parents had college savings predicted by all covariates using one-to-one nearest-neighborhood matching. Propensity score analysis balances the treatment group (i.e., those with savings accounts) on covariates to obtain more accurate estimates of the treatment effects. This method involves matching and weighting cases to create new samples and performing covariate balance checks (D'Agostino, 1998). Following the estimation of the propensity scores, we used two methods of propensity score analysis, including nearest-neighbor matching with caliper matching and propensity score weighting. Matching typically reduces the sample size because of the inability to match all treated and non-treated observations (Guo and Fraser, 2010; Rosenbaum, 2002; Rosenbaum and Rubin, 1985), which could result in a loss of a statistical power of the treatment effect on outcome estimation. Propensity score weighting was used as a non-sample-reducing correction to selection bias.

Propensity Score Estimation. Logistic regressions were performed to estimate propensity scores (i.e., the predicted probability of parents having a savings account for their child's college education in 2002). Prior to estimating the propensity scores, we conducted a series of logistic regressions to determine the covariates affecting selection bias. The results of these tests revealed significant differences among most covariates.

Covariate Balance Checks. We conducted balance checks to determine the ability of the propensity score analyses to balance relevant covariates. Given the potential selection bias evident among the covariates, balance checks were necessary to determine whether propensity score analyses adjusted for observed bias (Barth, Guo, and McCrae, 2008; D’Agostino, 1998; Guo, Barth, and Gibbons, 2006; Guo and Fraser, 2010). We performed all balance checks using weighted simple logistic regression (Guo and Fraser, 2010). Complete balance was achieved.

One-to-One Nearest-Neighbor Matching with Caliper Matching. After estimating propensity scores, we performed one-to-one nearest-neighbor matching (or, for brevity, oneto-one matching) with caliper matching (Cochran and Rubin, 1973). Parents with savings accounts (i.e., treated) and without savings accounts (i.e., non-treated) were ordered randomly. Then a treated parent was selected and matched with a non-treated parent using the closest propensity score within the region of the caliper (Guo and Fraser, 2010). The caliper size was equal to 0.1 times the standard deviation of the obtained propensity score. The matched pair was not used in matching other pairs (i.e., matching without replacement).

Average Treatment Effect. The estimated propensity scores were also used to compute the average treatment effect (ATE) for the population. The ATE weight estimated the ATE for the population using $(1 /(1-\mathrm{ps})$, where ps indicates propensity score) when cases are among the non-treatment group and (1/ps) when the cases are among the treatment group. Propensity scores ranged from 0.08 to 0.89 .

\section{Multilevel Modeling}

Multilevel (hierarchical linear) modeling was performed on three student loan debt outcomes predicted by the variables shown in the boxed insert (Raudenbush and Bryk, 2002). 


\section{Variables Used for Multilevel (Hierarchical Linear) Modeling}

Demographic variables

- Race

- Gender

- GPA

Student variables

- Students' perceptions of the following:

College costs as very important

Financial aid as very important

College choice based on cost

Amount expected to borrow

Parental income and education

Number of siblings
High school variables

- Percent of students from high school who attend a four-year college

- Visiting high school counselors before college

\section{University variables}

- Applying for financial aid

- Out-of-state residency

- Dependent status

- School selectivity

Random intercept and slope were determined. Students were nested within schools. The intraclass correlation coefficient was 0.142 .

Findings at significance levels of $p<0.05$ are noted in the tables. We also reported odds ratios (ORs) for easier interpretation. The OR is a measure of effect size describing the strength of association. All data analysis steps were conducted using Stata (version 13). ${ }^{1}$

\section{Sensitivity Analyses for Unobserved Heterogeneity}

Although propensity score analysis was used to account for selection bias among observed covariates, bias could still be present because of unobserved covariates (Rosenbaum, 2002). This type of selection bias, also referred to as hidden bias or unobserved heterogeneity, may have been present because potentially important covariates could have been unknowingly omitted from the model. Mantel-Haenszel ( $\mathrm{MH}$ ) tests were conducted using the mhbounds procedure in Stata (version 13) to account for unobserved heterogeneity that may have affected selection into treated and non-treated groups (see Becker and Caliendo, 2007). ${ }^{2} \mathrm{MH}$ tests were used to calculate the bounds to check sensitivity of the ATE weight results (Aakvik, 2001). Q represents the $\mathrm{MH}$ test statistic. The level of gamma $(\Gamma)$, a range of possible values attributable to unobserved heterogeneity, was set from 1 to 2 with an increment of 0.05 . A $\Gamma$ value close to 1 and significant indicates sensitivity to unobserved heterogeneity (Rosenbaum, 2005). Sensitivity analyses were conducted for the student debt (yes/no) outcome variable.

\section{RESULTS}

\section{Descriptive Results}

We discuss highlights of descriptive findings here; for additional information see Table 1. Among 2002 high school sophomores who graduated from a four-year college by 2012, 29 percent perceived that college costs were very important in choosing a college, 52 percent perceived 
Elliott, Lewis, Grinstein-Weiss, Nam

\section{Table 1}

\section{Weighted Descriptive Statistics}

\begin{tabular}{|c|c|c|}
\hline \multirow[b]{2}{*}{ Categorical variables } & \multicolumn{2}{|c|}{ Full $(\mathrm{N}=2,992)$} \\
\hline & Frequency & Percent \\
\hline \multicolumn{3}{|l|}{ Student variables } \\
\hline White & 2,233 & 75 \\
\hline Male & 1,637 & 55 \\
\hline GPA (reference 2.00 or lower) & 203 & 7 \\
\hline GPA $(2.01-2.50)$ & 197 & 7 \\
\hline GPA (2.51-3.00) & 513 & 17 \\
\hline GPA (3.01-3.50) & 991 & 33 \\
\hline GPA (3.51-4.00) & 1,088 & 36 \\
\hline Student perceives low college costs as very important & 856 & 29 \\
\hline Student perceives financial aid as very important & 1,562 & 52 \\
\hline Student perceives college choice is based on college cost & 1,575 & 53 \\
\hline Amount expected to borrow in the future (reference $\$ 0-\$ 1,999$ ) & 1,333 & 47 \\
\hline Amount expected to borrow in the future $(\$ 2,000-\$ 19,999)$ & 934 & 33 \\
\hline Amount expected to borrow in the future $(\$ 20,000$ or more) & 545 & 19 \\
\hline \multicolumn{3}{|l|}{ Parental/household variables } \\
\hline Low income (reference $\$ 35,000$ or below) & 885 & 30 \\
\hline Moderate income $(\$ 35,001-\$ 75,00)$ & 1,040 & 35 \\
\hline Middle income $(\$ 75,001-\$ 100,000)$ & 467 & 16 \\
\hline High income $(\$ 100,001$ or higher $)$ & 601 & 20 \\
\hline Parental education (reference high school or less) & 428 & 14 \\
\hline Some college & 548 & 18 \\
\hline Two-year college degree & 284 & 10 \\
\hline Four-year college degree or higher & 1,731 & 58 \\
\hline Number of siblings (reference 0 or 1 ) & 690 & 23 \\
\hline Number of siblings (2) & 1,141 & 38 \\
\hline Number of siblings (3) & 746 & 25 \\
\hline Number of siblings ( 4 or more siblings) & 416 & 14 \\
\hline \multicolumn{3}{|l|}{ Secondary school variables } \\
\hline 50 percent or more of students from high school attend four-year college & 1,700 & 57 \\
\hline \multicolumn{3}{|l|}{ College counseling } \\
\hline \multicolumn{3}{|l|}{ College or university variables } \\
\hline Student applied for financial aid & 2,370 & 79 \\
\hline Out-of-state residency & 720 & 24 \\
\hline Student lives with parents & 792 & 27 \\
\hline School selectivity (reference public university) & 2,006 & 67 \\
\hline Private, not-for-profit & 870 & 29 \\
\hline Private, for-profit & 110 & 4 \\
\hline \multicolumn{3}{|l|}{ Outcome variables } \\
\hline Has student loans & 2,049 & 69 \\
\hline Student loan thresholds (reference $\$ 0-\$ 1,999$ ) & 962 & 32 \\
\hline$\$ 2,000-\$ 19,999$ & 622 & 21 \\
\hline$\$ 20,000$ or more & 1,408 & 47 \\
\hline \multicolumn{3}{|l|}{ Variable of interest } \\
\hline Parental savings account to pay for student's college tuition & 1,297 & 49 \\
\hline Continuous outcome variable & Mean & Median \\
\hline Amount of student loans & $\$ 23,698$ & $\$ 17,000$ \\
\hline
\end{tabular}


that financial aid was very important in choosing a college, and 53 percent perceived they would have to choose a college based on cost. Forty-nine percent of parents of these students had savings to pay for their college. Of these students, 67 percent received their four-year degree from a public college; 29 percent from a private, not-for-profit college; and 7 percent from a private, for-profit college. Among these four-year college graduates, 69 percent have student loan debt; the average debt amount is $\$ 23,698$.

\section{Multivariate Analysis}

Here we write out only the results from ATE matching to conserve space. Results are consistent across the unadjusted, one-to-one matching, and ATE matching models with respect to direction and significance. Unadjusted and one-to-one matching results are available upon request. Results were similar to ATE results, so they are not included here.

\section{Student Loan Debt Results}

Table 2 presents results from a multilevel mixed-effects logistic regression predicting whether or not 2002 high school sophomores who graduated from a four-year college by 2012 have student loan debt. The ATE matching results indicate that among the variables controlled for in this study, parental savings for college is the only factor that reduces the probability of student loan debt (i.e., savings is a potential protective factor). Graduates whose parents had college savings for them as high school sophomores are about 39 percent less likely to have student loan debt than graduates whose parents did not have college savings for them as high school sophomores (see Table 2).

Positive significant predictors (i.e., potential risk factors) of student loan debt include the following:

- perceiving student financial aid as very important,

- expecting to have student loan debt of $\$ 2,000-\$ 19,999$,

- expecting to have student loan debt of $\$ 20,000$ or more versus expecting to have student loan debt of $\$ 0-\$ 1,999$,

- living in a moderate-income family $(\$ 35,001-\$ 75,000)$ as a sophomore compared with living in a low-income family (\$35,000 or below),

- applying for financial aid, and

- attending a private, for-profit college.

Positive predictors increase the probability that a student will report having student loan debt (i.e., risk factor). Four-year college graduates who as high school sophomores perceived financial aid as very important in choosing a college are 64 percent more likely to report having student loan debt than if they did not consider financial aid very important. They are about 12 percent more likely to have student loan debt if as sophomores they expected to borrow $\$ 2,000-\$ 19,999$ and about 15 percent more likely if they expected to borrow $\$ 20,000$ or more. Students from low-income ( $\$ 35,000$ or less) families are about 49 percent less likely to have student debt. If students applied for financial aid, they are two times more likely to have student debt than if they did not. Four-year college graduates who attend a private, not-for-profit col- 
Table 2

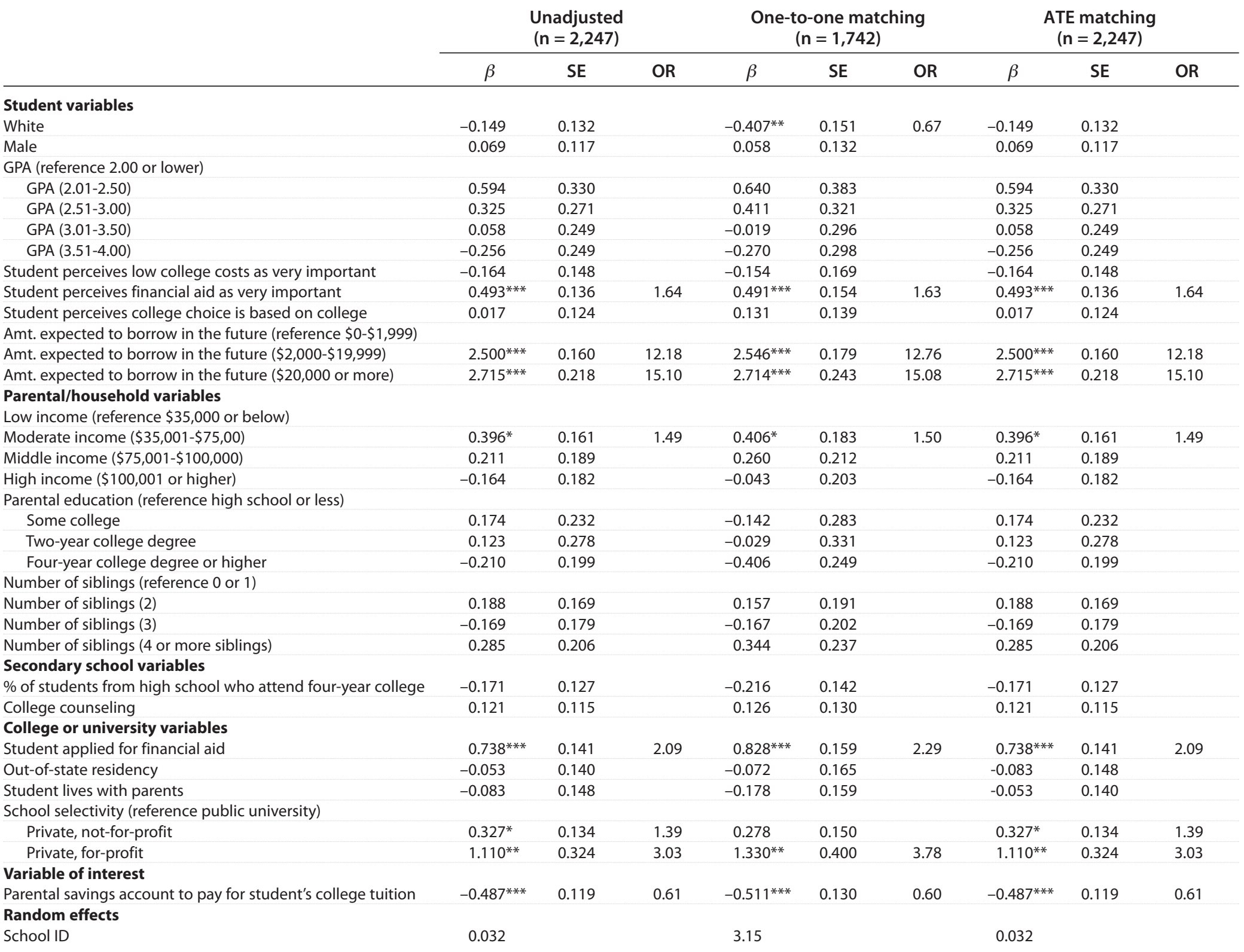

NOTE: $\beta$, regression coefficients; $\mathrm{SE}$, standard error; OR, odds ratio; ATE, the average treatment effect on the population. ${ }^{*},{ }^{* *}$, and ${ }^{* * *}$ indicate significance at the 5 percent, 1 percent, and 0.1 percent levels, respectively.

SOURCE: Data from the Educational Longitudinal Study. 
lege are 39 percent more likely to have student loan debt. If they attend a private, for-profit college, they are about three times more likely to have student loan debt than if they attend a public four-year college.

\section{Student Loan Debt Amounts}

Table 3 presents results from a multilevel mixed-effects linear regression on the amount of student loan debt. The ATE matching results indicate that among the variables controlled for in this study, male gender and parental college savings reduce the amount of student loan debt a four-year graduate from the sophomore class of 2002 has in 2012. Male graduates have $\$ 2,162.58$ less student loan debt than female graduates. Graduates whose parents had savings for them as high school sophomores have $\$ 3,208.88$ less student loan debt than graduates whose parents did not (see Table 3).

Conversely, four-year college graduates with high school sophomore GPAs of 2.01-2.50 have $\$ 7,849.32$ more student loan debt in 2012 than those with GPAs of 2.00 or lower. Students who perceived student financial aid as very important in choosing a college have $\$ 4,111.61$ more in student loan debt than those who did not. If students expected to have student loan debt of $\$ 2,000-\$ 19,999$ when they were high school sophomores, they have $\$ 14,076.03$ more in student loan debt than if they expected to have student loan debt of $\$ 0-\$ 1,999$. If they expected to have student loan debt of $\$ 20,000$ or more, they have $\$ 30,989.78$ more in student loan debt compared with graduates who expected to have debt of $\$ 2,000$ or less. College graduates from four-year colleges who as high school sophomores had four or more siblings have $\$ 4,740.54$ more student loan debt than similarly situated four-year graduates who as high school sophomores lived in a family with one or no siblings. Those who applied for financial aid have $\$ 4,604.17$ more in student loan debt than those who did not apply for financial aid in 2012. Graduates who attended a private, for-profit college have the highest amount of student debt in 2012. Graduates who attended a private, not-for-profit college have $\$ 6,934.69$ more student loan debt, and graduates who attended a private, for-profit college have $\$ 16,435.97$ more debt compared with college graduates who attended a public four-year college.

\section{Student Loan Debt Thresholds}

Table 4 presents results from a multilevel mixed-effects multinomial regression on the student loan debt threshold.

Borrowing Less than $\mathbf{\$ 2 , 0 0 0}$ Versus $\mathbf{\$ 2 , 0 0 0 - \$ 1 9 , 9 9 9}$. The ATE matching results in column (1) of Table 4 indicate that among the variables controlled for in this study, parental college savings is the only factor that reduces the log odds of having less than $\$ 2,000$ of student loan debt than of having $\$ 2,000-\$ 19,999$ of debt. A 2002 high school sophomore with parental college savings for them and who graduated from a four-year college by 2012 is 31 percent less likely to have $\$ 2,000$ - $\$ 19,999$ of student loan debt than to have less than $\$ 2,000$ of student loan debt compared with a 2002 high school sophomore whose parents had no college savings for them and who graduated from a four-year college by 2012.

Positive significant predictors of student loan debt threshold include the following: 
Table 3

Multilevel Mixed-Effects Linear Regression Predicting Amount of Student Loans Borrowed $(\mathbf{N}=\mathbf{2 , 9 9 2}$

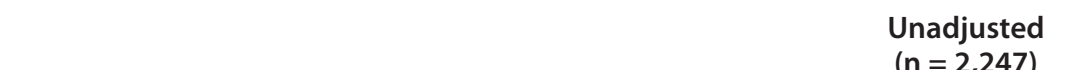

\begin{tabular}{|c|c|c|c|c|c|}
\hline \multicolumn{2}{|c|}{$\begin{array}{c}\text { Unadjusted } \\
(n=2,247)\end{array}$} & \multicolumn{2}{|c|}{$\begin{array}{l}\text { One-to-one matching } \\
(\mathrm{n}=1,742)\end{array}$} & \multicolumn{2}{|c|}{$\begin{array}{l}\text { ATE matching } \\
(\mathrm{n}=2,247)\end{array}$} \\
\hline$\beta$ & SE & $\beta$ & SE & $\beta$ & $\mathrm{SE}$ \\
\hline
\end{tabular}

\section{Student variables}

White

Male

GPA (reference 2.00 or lower)

GPA $(2.01-2.50)$

GPA (2.51-3.00)

GPA (3.01-3.50)

GPA (3.51-4.00)

Student perceives low college costs as very important

Student perceives financial aid as very important

Student perceives college choice is based on college

Amt. expected to borrow in the future (reference $\$ 0-\$ 1,999$ )

Amt. expected to borrow in the future $(\$ 2,000-\$ 19,999)$

Amt. expected to borrow in the future $(\$ 20,000$ or more)

Parental/household variables

Low income (reference $\$ 35,000$ or below)

Moderate income $(\$ 35,001-\$ 75,00)$

Middle income $(\$ 75,001-\$ 100,000)$

High income $(\$ 100,001$ or higher)

Parental education (reference high school or less)

Some college

Two-year college degree

Four-year college degree or higher

Number of siblings (reference 0 or 1 )

Number of siblings (2)

Number of siblings (3)

Number of siblings ( 4 or more siblings)

Secondary school variables

$\%$ of students from high school who attend four-year college

College counseling

College or university variables

Student applied for financial aid

Out-of-state residency

Student lives with parents

School selectivity (reference public college)

Private, not-for-profit

Private, for-profit

\section{Variable of interest}

Parental savings account to pay for student's college tuition

Random effects

School ID

$-1,459.14$

$-1,588.51$

7,618.93*

$3,150.33$

$4,142.29$

572.89

$-1,582.54$

$4,839.18^{* * *}$

$-1,542.66$

$1,2581.28^{* * *}$

$28,997.25^{* * *}$

$1,606.76$

$1,230.98$

$-3,476.63^{* *}$

$-2,350.54^{*}$

$1,287.98$

$1,134.30$

$3,069.18$

$2,350.42$

2,222.07

$2,198.57$

$1,405.31$

$1,339.50$

$1,272.60$

$9,582.71^{* *}$

$3,187.10$

$4,328.19$

2,067.61

$-1,695.11$

$5,028.69^{* * * *}$

$-699.55$

$3,272.81$

$2,764.72$

$2,585.29$

$2,596.77$

$1,404.93$

$1,300.45$

$1,181.58$

$14,105.90^{* * *}$

$2,134.93$

$30,145.28^{* * *}$

$1,360.20$

$1,640.18$

$-2,130.39$

$1,147.72$

$-2,162.58^{*}$

$7,849.32^{* *}$

$3,164.49$

$4,590.58$

$2,104.29$

$-1,279.63$

$4,111.61^{*}$

$-1,320.24$

$14,076.03^{* * *}$

$30,989.78^{* * *}$

$1,121.42$

$1,121.42 \quad 1,532.13$

$-1,919.63$

$1,808.74$
$1,854.35$

$2,256.12$

469.00

$-332.09$

$1,542.90$

$1,820.28$

$1,821.59$

$1,864.01$

$1,665.06$

$-3,076.17$

$-2,415.63$

$2,240.34$

$2,489.65$

$2,041.90$

$-1,434.00$

$-984.49$

$1,035.73$

$1,826.70$

$1,933.46$

$2,176.51$

$-843.99$

111.46

$2,340.55$

$2,682.56$

$2,092.49$

$1,661.31$

$2,364.43$

$5,594.93^{* *}$

$1,655.32$

$1,747.80$

$2,001.13$

$-475.44$

532.17

$1,223.42$

$-963.18$

$1,166.52$

$5,091.44^{* * *}$

1562.27

$-3,057.63^{*}$

$7,313.67^{* * *}$

$14,335.00^{* * * *}$

$-3,153.93^{*}$

$1,481.30$

$1,534.71$

$1,323.32$

$-392.27$

$1,247.29$

$1,118.27$

$4,636.18^{* *}$
-551.67

$1,521.68$

$1,377.64$

$-3,190.21^{*}$

$1,414.03$

$6,604.12^{* * *} \quad 1,270.88$

$14,469.98^{* * *}$

$3,093.34$

$-3,608.07^{* *}$

1103.74

5.13

NOTE: Values except random effects indicate U.S. dollars. $\beta$, regression coefficients; SE, standard error. ${ }^{*},{ }^{* *}$, and ${ }^{* * *}$ indicate significance at the 5 percent, 1 percent, and 0.1 percent levels, respectively.

SOURCE: Data from the Educational Longitudinal Study. 
Table 4

Multilevel Mixed-Effects Multinomial Predicting Amount of Student Loan Debt: ATE Matching (N= 2,992; $n=2,247)$

\begin{tabular}{|c|c|c|c|c|c|c|c|c|c|}
\hline Loan amount: & & 0 vs. & & & 0 vs. 2 & & & ) 1 vs. & \\
\hline & $\beta$ & SE & OR & $\beta$ & SE & OR & $\beta$ & SE & OR \\
\hline Student variables & & & & & & & & & \\
\hline White & -0.024 & 0.145 & & -0.089 & 0.146 & & -0.066 & 0.135 & \\
\hline Male & 0.168 & 0.130 & & -0.022 & 0.131 & & -0.191 & 0.121 & \\
\hline GPA (reference 2.00 or lower) & & & & & & & & & \\
\hline GPA (2.01-2.50) & -0.165 & 0.373 & & 0.383 & 0.366 & & 0.558 & 0.353 & \\
\hline GPA (2.51-3.00) & 0.275 & 0.297 & & 0.129 & 0.310 & & -0.143 & 0.285 & \\
\hline GPA (3.01-3.50) & -0.146 & 0.277 & & 0.133 & 0.286 & & 0.284 & 0.268 & \\
\hline GPA (3.51-4.00) & -0.278 & 0.276 & & -0.268 & 0.286 & & 0.016 & 0.268 & \\
\hline Student perceives low college costs as very important & -0.162 & 0.159 & & -0.194 & 0.160 & & -0.033 & 0.143 & \\
\hline Student perceives financial aid as very important & $0.304^{*}$ & 0.147 & 1.36 & $0.497^{* *}$ & 0.149 & 1.64 & 0.193 & 0.135 & \\
\hline Student perceives college choice is based on college & 0.113 & 0.135 & & -0.053 & 0.136 & & -0.165 & 0.125 & \\
\hline Amt. expected to borrow in the future (reference $\$ 0-\$ 1,999$ ) & & & & & & & & & \\
\hline Amt. expected to borrow in the future $(\$ 2,000-\$ 19,999)$ & $2.383^{* * *}$ & 0.160 & 10.84 & $2.515^{* * *}$ & 0.165 & 12.37 & 0.126 & 0.149 & \\
\hline Amt. expected to borrow in the future $(\$ 20,000$ or more) & $2.138^{* * *}$ & 0.227 & 8.48 & $3.351^{* * *}$ & 0.214 & 28.53 & $1.211^{* * *}$ & 0.177 & 3.36 \\
\hline $\begin{array}{l}\text { Parental/household variables } \\
\text { Low income (reference } \$ 35,000 \text { or below) }\end{array}$ & & & & & & & & & \\
\hline Moderate income $(\$ 35,001-\$ 75,00)$ & $0.516^{* *}$ & 0.174 & 1.68 & $0.381^{*}$ & 0.173 & 1.46 & -0.135 & 0.156 & \\
\hline Middle income $(\$ 75,001-\$ 100,000)$ & 0.383 & 0.207 & & 0.183 & 0.209 & & -0.203 & 0.193 & \\
\hline High income $(\$ 100,001$ or higher $)$ & -0.005 & 0.211 & & -0.188 & 0.211 & & -0.186 & 0.211 & \\
\hline Parental education (reference high school or less) & & & & & & & & & \\
\hline Some college & 0.153 & 0.245 & & 0.303 & 0.243 & & 0.153 & 0.215 & \\
\hline Two-year college degree & 0.186 & 0.289 & & 0.158 & 0.291 & & -0.028 & 0.253 & \\
\hline Four-year college degree or higher & 0.025 & 0.214 & & -0.077 & 0.215 & & -0.103 & 0.195 & \\
\hline Number of siblings (reference 0 or 1 ) & & & & & & & & & \\
\hline Number of siblings (2) & 0.154 & 0.184 & & 0.340 & 0.195 & & 0.187 & 0.180 & \\
\hline Number of siblings (3) & -0.171 & 0.197 & & 0.215 & 0.204 & & $0.386^{*}$ & 0.191 & 1.47 \\
\hline Number of siblings ( 4 or more siblings) & 0.069 & 0.225 & & $0.696^{* *}$ & 0.227 & 2.01 & $0.630^{* *}$ & 0.207 & 1.88 \\
\hline Secondary school variables & & & & & & & & & \\
\hline$\%$ of students from high school who attend four-year college & -0.181 & 0.139 & & -0.186 & 0.141 & & -0.003 & 0.127 & \\
\hline College counseling & 0.101 & 0.126 & & 0.077 & 0.128 & & -0.023 & 0.118 & \\
\hline College or university variables & & & & & & & & & \\
\hline Student applied for financial aid & $0.660^{* * *}$ & 0.173 & 1.93 & $0.575^{* *}$ & 0.179 & 1.78 & -0.084 & 0.197 & \\
\hline Out-of-state residency & -0.110 & 0.164 & & 0.014 & 0.161 & & 0.123 & 0.148 & \\
\hline Student lives with parents & 0.124 & 0.153 & & -0.143 & 0.160 & & -0.271 & 0.149 & \\
\hline School selectivity (reference public college) & & & & & & & & & \\
\hline Private, not-for-profit & 0.273 & 0.147 & & $0.533^{* * *}$ & 0.146 & 1.70 & $0.263^{*}$ & 0.133 & 1.30 \\
\hline Private, for-profit & 0.675 & 0.370 & & $1.594^{* * *}$ & 0.334 & 4.92 & $0.919 * *$ & 0.324 & 2.51 \\
\hline Variable of interest & & & & & & & & & \\
\hline Parental savings account to pay for student's college tuition & $-0.364^{* *}$ & 0.131 & 0.69 & $-0.515^{* * *}$ & 0.133 & 0.60 & -0.150 & 0.123 & \\
\hline Random effects & & & & & & & & & \\
\hline School ID & 0.099 & & & 0.099 & & & 0.033 & & \\
\hline
\end{tabular}

School ID

0.099

0.099

$2=\$ 20,000$ or more. ${ }^{*}, * *$, and ${ }^{* *}$ indicate significance at the 5 percent, 1 percent, and 0.1 percent levels, respectively.

SOURCE: Data from the Educational Longitudinal Study. 
- perceiving student financial aid as very important,

- expecting to have student loan debt of $\$ 2,000-\$ 19,999$,

- expecting to have student loan debt of $\$ 20,000$ or more,

- living in a moderate-income family $(\$ 35,001-\$ 75,000)$ as a sophomore compared with living in a low-income family ( $\$ 35,000$ or below), and

- applying for financial aid.

Four-year graduates who perceived financial aid as very important in choosing a college are about 36 percent more likely to have $\$ 2,000$ - $\$ 19,999$ of student loan debt than to have less than $\$ 2,000$ of debt. They are about 11 times more likely to have $\$ 2,000-\$ 19,999$ in student loan debt than to have less than $\$ 2,000$ if as sophomores they expected to borrow $\$ 2,000$ - $\$ 19,999$ and about 8 times more likely if they expected to borrow $\$ 20,000$ or more compared with expecting to borrow less than $\$ 2,000$. Four-year graduates in moderate-income families as sophomores are 68 percent more likely to have $\$ 2,000$ - $\$ 19,999$ in student loan debt than to have less than $\$ 2,000$ compared with four-year college graduates in low-income families as high school sophomores. Four-year college graduates who applied for financial aid are about two times more likely to have $\$ 2,000-\$ 19,999$ in student debt than less than $\$ 2,000$ compared with four-year college graduates who did not apply for financial aid.

Borrowing Less than $\mathbf{\$ 2 , 0 0 0 ~ V e r s u s ~} \mathbf{\$ 2 0 , 0 0 0}$ or More. The results in column (2) of Table 4 indicate that a 2002 high school sophomore with parental college savings for them and who graduated from a four-year college by 2012 is 40 percent less likely to have $\$ 20,000$ or more of student loan debt than to have less than $\$ 2,000$ of student loan debt compared with a 2002 high school sophomore who had parents with no college savings for them and who graduated from a four-year college by 2012.

Positive significant predictors of student loan debt threshold include the following:

- perceiving student financial aid as very important,

- expecting to have student loan debt of $\$ 2,000-\$ 19,999$,

- expecting to have student loan debt of $\$ 20,000$ or more,

- living in a moderate-income family $(\$ 35,001-\$ 75,000)$ as a sophomore compared with living in a low-income family ( $\$ 35,000$ or below),

- living in a family as a sophomore with four or more siblings,

- applying for financial aid, and

- attending a private college (not-for-profit or for-profit).

Four-year graduates who perceived financial aid as very important are about 64 percent more likely to have $\$ 20,000$ or more in student loan debt than to have less than $\$ 2,000$. They are about 12 times more likely to have $\$ 20,000$ or more of debt than less than $\$ 2,000$ if as sophomores they expected to borrow $\$ 2,000$ - $\$ 19,999$. They are also about 29 times more likely to have $\$ 20,000$ or more of debt if they expected to borrow $\$ 20,000$ or more than if they expected to borrow less than $\$ 2,000$. Four-year college graduates in moderate-income families as sophomores are 46 percent more likely to have $\$ 20,000$ or more of debt than to have less than $\$ 2,000$ compared with graduates in low-income families as sophomores. Graduates who lived in fami- 
lies with four or more siblings as sophomores are about two times more likely to have student debt of $\$ 20,000$ or more than to have less than $\$ 2,000$. Four-year college graduates who applied for financial aid are about 78 percent more likely to have $\$ 20,000$ or more in student debt than to have less than $\$ 2,000$ compared with four-year college graduates who did not apply for financial aid. Graduates who attended a private, not-for-profit college instead of a public college are about 70 percent more likely to have student debt of $\$ 20,000$ or more than to have less than $\$ 2,000$. Graduates who attended a private, for-profit college instead of a public college are close to five times more likely to have student debt of $\$ 20,000$ or more than to have less than $\$ 2,000$.

Borrowing \$2,000-\$19,999 Versus $\mathbf{\$ 2 0 , 0 0 0}$ or More. The evidence in column (3) of Table 4 suggests that no factors reduce the odds of having the highest debt amount versus the middle debt amount. Positive significant predictors of the student loan debt threshold include the following:

- expecting to have student loan debt of $\$ 20,000$ or more compared with expecting to have less than $\$ 2,000$,

- living in a family as a sophomore with three or more siblings compared with living in a family with one or no siblings, and

- applying for financial aid, and

- attending a private college (not-for-profit or for-profit).

Four-year college graduates are more than three times more likely to have $\$ 20,000$ or more in student loan debt than to have $\$ 2,000-\$ 19,999$ of debt if as sophomores they expected to borrow $\$ 20,000$ or more compared with expecting to borrow less than $\$ 2,000$. If students lived in families with three siblings compared with living in families with one or no siblings, they are about 47 percent more likely to have $\$ 20,000$ or more of debt than $\$ 2,000-\$ 19,999$ and 88 percent more likely if they lived in families with four siblings or more. Students who attended a private, not-for-profit college instead of a public college are 30 percent more likely to have student debt of $\$ 20,000$ or more instead of debt of $\$ 2,000-\$ 19,999$. Students who attended a private, for-profit college instead of a public college are almost two and a half times more likely to have student debt of $\$ 20,000$ than to have debt of $\$ 2,000-\$ 19,999$.

\section{Sensitivity of the Results to Unobserved Heterogeneity}

The results for student loan debt seem moderately robust against potential hidden bias. For student loan debt, the bounds under the assumption that we overestimated the treatment effect (i.e., $Q+\mathrm{MH}$ ) revealed that at relatively high $\Gamma$ values, the results become insignificant (Table 5). Specifically, the results would no longer be significant with a value of $\Gamma=1.50$ $(p=0.000)$.

\section{DISCUSSION}

Given the growing amount of student loan debt in the United States today (Fry, 2012) and the growing evidence that student debt can potentially have negative effects on the financial 


\section{Table 5}

\section{Sensitivity Analyses for Unobserved Heterogeneity}

\begin{tabular}{|c|c|}
\hline$\Gamma$ & $\begin{array}{c}\text { Student Loan Debt in } 2012 \\
\text { Q-MH+ }\end{array}$ \\
\hline 1.000 & 4.313 \\
\hline 1.050 & 4.795 \\
\hline 1.100 & 5.255 \\
\hline 1.150 & 5.695 \\
\hline 1.200 & 6.117 \\
\hline 1.250 & 6.523 \\
\hline 1.300 & 6.914 \\
\hline 1.350 & 7.290 \\
\hline 1.400 & 7.654 \\
\hline 1.450 & 8.006 \\
\hline 1.500 & $8.347^{* * *}$ \\
\hline 1.550 & $8.678^{* * *}$ \\
\hline 1.600 & $8.998^{* * *}$ \\
\hline 1.650 & $9.310^{* * *}$ \\
\hline 1.700 & $9.613^{* * *}$ \\
\hline 1.750 & $9.908^{* * *}$ \\
\hline 1.800 & $10.195^{* * *}$ \\
\hline 1.850 & $10.475^{* * *}$ \\
\hline 1.900 & $10.748^{* * *}$ \\
\hline 1.950 & $11.015^{* * *}$ \\
\hline 2.000 & $11.276^{* * *}$ \\
\hline
\end{tabular}

NOTE: $Q$ - MH+ represents the Mantel-Haenszel statistic for overestimation of treatment effect. *** indicates significance at the 0.1 percent level.

SOURCE: Data from the Educational Longitudinal Study.

well-being of students after college graduation (Elliott and Nam, 2013, and Hiltonsmith, 2013), finding ways to reduce college debt has become increasingly important for maintaining education as the great equalizer in society. Consistent with other national estimates of student indebtedness, the typical four-year graduate in this study has about $\$ 24,000$ in student loan debt. Evidence suggests that the debt load of these graduates will have significant effects on their asset accumulation (Elliott and Lewis, 2013), their personal financial ability, and their preparation for their own children's education-as well as effects on the larger economy.

In the first part of this study, we asked whether parental college savings for their high school sophomore's higher education acts as a potential protective factor against student loan debt after graduation from a four-year college. We find that, in this study, parental college savings does reduce the odds of a four-year college graduate having student loan debt. While we found nothing else that reduced the odds of graduates having student debt, several factors 
were obvious potential risk factors. For example, it is interesting to note that four-year graduates from moderate-income $(\$ 35,001-\$ 75,000)$ families had higher odds of having student debt than four-year college graduates from low-income (below $\$ 35,000$ ) families. This finding is consistent with other research suggesting that moderate-income students have been hardest hit by the combination of student loan debt, the shift toward merit-based aid, and the escalation of college prices (Choy, Berker, and Carroll, 2003, and Elliott and Friedline, 2012). For example, according to data from full-time dependent students from the 1999-2000 National Postsecondary Student Aid Study, 51 to 59 percent of students from low- and moderate-income households pay with loans compared with 27 to 49 percent of students from middle- and high-income households (Choy, Berker, and Carroll, 2003). Further, a number of studies have discussed how some students are loan averse and thereby have less-certain job prospects, less familiarity with financial institutions, and a higher likelihood of not graduating from college (Kim, 2007). If it is true that some students are loan averse, the opposite also appears to be true. Evidence in this study on the amount students expect to borrow may be interpreted as suggesting that students have much higher odds of borrowing for college if they are inclined to borrow. This suggests a potential future increase in student borrowing, even as the "culture" of college financing becomes even more completely debt-dependent, a collective narrative that could shape prospective students' orientation toward high-dollar debt. Future researchers may want to examine the predictors of why some students have higher odds of borrowing than other students. Also consistent with previous research, our findings suggest that students who attend private, forprofit colleges have higher odds of student loan debt than graduates from public or private, not-for-profit colleges (Deming, Goldin, and Katz, 2011). These findings should be considered as part of the ongoing policy and research conversations about the interaction between institutional practices and characteristics and student outcomes.

In the second part of the study, we examined whether parental college savings for their child reduces the amount of student loan debt the student will have upon graduation. Student gender and parental savings appear to act as protective factors for the total amount of college debt. Consistent with findings by Dwyer, McCloud, and Hodson (2012), we find evidence that male students have about \$2,163 less student loan debt than female students. Graduates whose parents had savings for them when they were sophomores in high school have about \$3,209 less debt. Of note, among the risk factors for more student loan debt is college choice: Graduates who attend private, for-profit colleges have about $\$ 16,436$ more student debt than graduates who attend public colleges.

In the third part of our study, we examined whether the effects of parental college savings for their child may vary at different student debt thresholds. Results suggest that for four-year college graduates whose parents saved for their college education, the odds of borrowing what might be considered high-dollar student loans (defined here as $\$ 20,000$ or more) are lower than for students whose parents had no college savings. High-dollar loans are of particular interest because they may be the most damaging to persistence and graduation from college (Dwyer, McCloud, and Hodson, 2011; Dwyer, McCloud, and Hodson, 2012; Paulsen and St. John, 2002). In addition, the negative effects of student indebtedness on asset accumulation and other milestones of household economic security are often extended for those with high-dollar debts, 
which of course require more time to repay. High-dollar student loan debt is also associated with a greater risk of delinquency for student debt and other types of borrowing (Lee, 2013).

We find that a number of factors increase the likelihood of a student obtaining a highdollar loan. The amount of money children expect to borrow in the future is a very strong predictor of whether students actually obtain student loans. Students who expected to borrow $\$ 10,000$ or more were far more likely to borrow high-dollar amounts. Some research suggests that students may gain a boost in self-esteem and a sense of mastery from obtaining student loans, which may encourage them to acquire additional loans. However, this sense of mastery begins to fade over time (Dwyer, McCloud, and Hodson, 2011). Additional research suggests that students are more likely to drop out of college once loan totals become too high $(\$ 10,000$ or more), which might occur because students with high-dollar loans early in their college careers do not have realistic expectations of what they can afford to repay (Dwyer, McCloud, and Hodson, 2011, 2012). As more reasonable expectations are formed, students become more averse to obtaining additional loans necessary to finish and graduate. However, more research is necessary to understand this potential relationship.

Further, consistent results from the nearest-neighbor matching and ATE weighting suggest that the effect of parental college savings on reducing student loan debt is robust (i.e., the results are insensitive to selection bias given the covariates in the models).

\section{Limitations}

One limitation of this study is the use of propensity score weighting, which may increase random error in estimates due to endogeneity and specification of the propensity score estimation equation (Freedman and Berk, 2008). In some cases, propensity score weighting has been found to exaggerate endogeneity (Freedman and Berk, 2008). More specifically, parental college savings may be endogenous if assignment into treatment groups correlates with unobserved covariates that affect college enrollment and graduation. Endogeneity may be introduced by unknowingly omitting relevant or important covariates. In this study, concerns regarding endogeneity can be mitigated somewhat because we used two propensity score analyses (i.e., pair matching and propensity score weighting) to cross-validate the results from the two models that adjust for selection bias given the observed covariates.

\section{Implications}

Public policymakers, educators, economists, and higher education consumers are searching together for approaches capable of reducing the effects of student borrowing on the educational trajectories and later financial futures of a generation of young people in the United States. If parental savings is one of the few reliable and significant ways to reduce students' assumption of high-dollar debt, even though parental savings is currently inadequate to protect most students from an indebted future (Sallie Mae, 2013), policies to facilitate, encourage, and even subsidize parental savings may be worthwhile public investments. Certainly, tax incentives may be part of this policy mix, including reforms to increase the refundability and improve the timing of current supports (Huelsman, 2010). Additionally, providing parents with better access to workable savings vehicles by changing the operations of 529 college sav- 
ings plans (Newville, 2010) and, perhaps, linking college savings opportunities to employers may better equip parents to perform this important protective function in their children's lives.

Given the long-term trends in college financing and the increasing shift of college costs from society to individual students and families, it is clear that parents will need new tools to meet the challenge of saving as an alternative to student borrowing. The evidence today suggests that households with the greatest need for education savings-low- and moderateincome households, those most negatively affected by the almost-certain burden of student loan debt and most likely to have their educational options curtailed by inadequate options for college financing-are the least equipped to rise to the challenge of educational asset accumulation (Sallie Mae, 2013).

\section{CONCLUSION}

One long-standing policy argument for adopting children's savings accounts (CSAs) has been that they can help reduce the amount of college debt when students leave school, but no research has confirmed this claim. In this study, we find evidence to suggest that parental college savings can be part of a strategy to help reduce college debt. These findings may be not only theoretically significant, but also immediately and politically relevant, as asset practitioners and advocates search for the means to make a compelling case for CSAs as a solution to student debt and its educational and financial effects at the household and aggregate levels. However, even if small-dollar savings accounts for college improve enrollment and graduation rates (Assets and Education Initiative, 2013), CSAs must be adequately funded to effectively reduce debt. To best wield CSAs as a tool to support students' educational attainment, their effects must be understood on multiple levels. The likelihood of students, first, making it to college enrollment and then persisting through graduation may increase significantly with even small levels of asset ownership (Elliott, 2013). However, forestalling high levels of student debt and the potentially negative financial and educational effects associated with such borrowing will require larger savings balances, particularly since the savings of low-income participants in CSAs have tended to be fairly limited (see Mason et al., 2009). For example, descriptive data tell us that low-income children (38 percent) are far less likely to have a savings account than are higher-income children (69 percent) (Friedline, 2012). Realizing the full potential of asset-based college financing approaches may require that policies rely significantly on redistributive measures (e.g., initial deposits, matching, and incentives) capable of combating the challenges within today's higher education landscape. Understanding these investments as potentially significant protections against the student debt problem may increase their political viability and clarify their importance in U.S. educational and economic policy. 


\section{Elliott, Lewis, Grinstein-Weiss, Nam}

\section{NOTES}

1 Stata syntax is as follows: xi:xtmelogit used for the dichotomous outcome variable (i.e., student debt); xi:xtmixed used for the continuous outcome variable (i.e., amount borrowed); and xi:gllamm used for the three-level outcome variable (i.e., student debt threshold).

2 The mhbounds procedure is a user-written program in Stata used to test the sensitivity of the analysis to the influence of unobserved factors (i.e., factors not controlled for in the model) when there is a categorical dependent variable.

\section{REFERENCES}

Aakvik, Arild. "Bounding a Matching Estimator: The Case of a Norwegian Training Program." Oxford Bulletin of Economics and Statistics, February 2001, 63(1), pp. 115-43.

Assets and Education Initiative. "Building Expectations, Delivering Results: Asset-Based Financial Aid and the Future of Higher Education," in Elliott, W., ed., Biannual Report on the Assets and Education Field. Lawrence, KS: Assets and Education Initiative, July 2013.

Azziz, Riccardo. “The Great Debate: Is College Still Worth It?" The Blog, Huffington Post, January 9, 2014; http://www.huffingtonpost.com/dr-ricardo-azziz/debate-college-worth_b_4561068.html (accessed April 14, 2014).

Barth, Richard P.; Guo, Shenyang and McCrae, Julie S. "Propensity Score Matching Strategies for Evaluating the Success of Child and Family Service Programs." Research on Social Work Practice, May 2008, 18(3), pp. 212-22; doi:10.1177/1049731507307791.

Becker, Sascha O. and Caliendo, Marco. "Sensitivity Analysis for Average Treatment Effects." Stata Journal, February 2007, 7(1), pp. 71-83.

Boshara, Ray and Emmons, William. "After the Fall: Rebuilding Family Balance Sheets, Rebuilding the Economy," in Annual Report 2012. Federal Reserve Bank of St. Louis, May 2013, pp. 4-15; http://www.stlouisfed.org/publications/ar/2012/pages/ar12_2a.cfm.

Campaigne, David A. and Hossler, Don. "How Do Loans Affect the Educational Decisions of Students? Access, Aspirations, College Choice, and Persistence," in Richard Fossey and Mark Bateman, eds., Condemning Students to Debt: College Loans and Public Policy. New York: Teachers College Press, 1998, pp. 85-104.

Carnevale, Anthony P.; Rose, Stephen J. and Cheah, Ban. "The College Payoff: Education, Occupations, Lifetime Earnings." Georgetown University Center for Education and the Workforce, August 5, 2011; http://cew.georgetown.edu/collegepayoff.

Castleman, Benjamin L. and Long, Bridget Terry. "Looking Beyond Enrollment: The Causal Effect of Need-Based Grants on College Access, Persistence, and Graduation." NBER Working Paper No. 19306, National Bureau of Economic Research, August 2013; http://www.nber.org/papers/w19306.pdf.

Center for the Study of Education Policy. Grapevine: An Annual Compilation of Data on State Fiscal Support for Higher Education. Normal, IL: Illinois State University, 2013; http://grapevine.illinoisstate.edu/.

Chopra, Rohit. "Generation Debt: The Perils, Promise, and Future of Student Loans." Keynote address at conference sponsored by the Center for Household Financial Stability, Federal Reserve Bank of St. Louis, November 18, 2013; https://www.youtube.com/watch?v=xgGYl3jNUzo.

Choy, Susan P.; Berker, Ali M. and Carroll, C. Dennis. How Families of Low- and Middle-Income Undergraduates Pay for College: Full-Time Dependent Students in 1999-2000. Publication No. NCES 2003-162. Washington, DC: US Department of Education National Center for Education Statistics, June 2003; http://nces.ed.gov/das/epubs/pdf/2003162_es.pdf.

Cochran, William G. and Rubin, Donald B. "Controlling Bias in Observational Studies: A Review." Sankhya: The Indian Journal of Statistics, Series A, December 1973, 35(4), pp. 417-46.

Cofer, Jamnes and Somers, Patricia. "What Influences Persistence at Two-Year Colleges?" Community College Review, Winter 2001, 29(3), pp. 56-76. 
College Board. Trends in College Pricing 2012. Trends in Higher Education Series. New York: College Board, 2012a; http://trends.collegeboard.org/sites/default/files/college-pricing-2012-full-report_0.pdf.

College Board. Trends in Student Aid 2012. Trends in Higher Education Series. New York: College Board, 2012b; http://trends.collegeboard.org/sites/default/files/student-aid-2012-full-report.pdf.

College Board. Trends in Student Aid 2013. Trends in Higher Education Series. New York: College Board, 2013; http://trends.collegeboard.org/sites/default/files/student-aid-2013-full-report.pdf.

Cramer, Reid; O'Brien, Rourke; Cooper, Daniel and Luengo-Prado, Maria. "A Penny Saved Is Mobility Earned: Advancing Economic Mobility Through Savings." Philadelphia, PA: Pew Charitable Trusts, November 2, 2009; http://www.pewtrusts.org/en/research-and-analysis/reports/0001/01/01/a-penny-saved-is-mobility-earned.

Cunningham, Alisa F. and Santiago, Deborah A. Student Aversion to Borrowing: Who Borrows and Who Doesn't. Washington, DC: Institute for Higher Education Policy, December 2008; http://www.nyu.edu/classes/jepsen/ihep2008-12.pdf.

D’Agostino, Ralph B. Jr. "Propensity Score Methods for Bias Reduction in the Comparison of a Treatment to a NonRandomized Control Group." Statistics in Medicine, October 1998. 17(19), pp. 2265-81.

Deming, David J.; Goldin, Claudia and Katz, Lawrence F. "The For-Profit Postsecondary School Sector: Nimble Critters or Agile Predators?" NBER Working Paper No. 17710; National Bureau of Economic Research, December 2011; http://www.nber.org/papers/w17710.

Desrochers, Donna M.; Lenihan, Colleen M. and Wellman, Jane V. Trends in College Spending: 1998-2008. Washington, DC: Delta Cost Project, 2010;

http://www.deltacostproject.org/sites/default/files/products/Trends-in-College-Spending-98-08.pdf.

Dowd, Alicia C. and Coury, Tarek. "The Effect of Loans on the Persistence and Attainment of Community College Students." Research in Higher Education, February 2006, 47(1), pp. 33-62.

Dwyer, Rachel E.; McCloud, Laura and Hodson, Randy. "Youth Debt, Mastery, and Self-Esteem: Class-Stratified Effects of Indebtedness on Self-Concept." Social Science Research, May 2011, 40(3), pp. 727-741; doi:10.1016/j.ssresearch.2011.02.001.

Dwyer, Rachel E.; McCloud, Laura and Hodson, Randy. "Debt and Graduation from American Universities." Social Forces, June 2012, 90(4), 1133-55.

Elliott, William. "Small-Dollar Children's Savings Accounts and Children's College Outcomes." Children and Youth Services Review, March 2013, 35(3), pp. 572-85.

Elliott, William and Beverly, Sondra G. "The Role of Savings and Wealth in Reducing 'Wilt' Between Expectations and College Attendance." Journal of Children and Poverty, November 2011a, 17(2), pp. 165-85.

Elliott, William and Beverly, Sondra G. "Staying on Course: The Effects of Assets and Savings on the College Progress of Young Adults." American Journal of Education, May 2011b, 117(3), pp. 343-74.

Elliott, W.; Choi, Eun H.; Destin, Mesmin and Kim, Kevin H. "The Age Old Question, Which Comes First? A Simultaneous Test of Young Adult's Savings and Expectations." Children and Youth Services Review, July 2011, 33(7), pp. 1101-11.

Elliott, William; Destin, Mesmin and Friedline, Terri. "Taking Stock of Ten Years of Research on the Relationship Between Assets and Children's Educational Outcomes: Implications for Theory, Policy and Intervention." Children and Youth Services Review, November 2011, 33(11), pp. 2312-28.

Elliott, William and Friedline, Terri. "'You Pay Your Share, We'll Pay Our Share': The College Cost Burden and the Role of Race, Income, and College Assets." Economics of Education Review, April 2012, 33, pp. 134-53; doi: http://dx.doi.org/10.1016/j.econedurev.2012.10.001.

Elliott, William and Lewis, Melinda. "Student Loans Are Widening the Wealth Gap in America: Time to Focus on Equity." Lawrence, KS: Assets and Education Initiative (AEDI), November 7, 2013; http://save2limitdebt.com/wp-content/uploads/2013/11/Student-Loans-Widening-Wealth-Gap_Fullreport.pdf.

Elliott, William and Lewis, Melinda. "Harnessing Assets To Build an Economic Mobility System: Reimagining the American Welfare System." Lawrence, KS: Assets and Education Initiative (AEDI); 2014; http://assetsformobility.com/wp-content/uploads/2014/03/Feb-2014-AEDI-report_030614.pdf. 


\section{Elliott, Lewis, Grinstein-Weiss, Nam}

Elliott, William and Nam, IISung. "Is Student Debt Jeopardizing the Short-Term Financial Health of U.S. Households?" Federal Reserve Bank of St. Louis Review, September/October 2013, 95(5), pp. 405-24; http://research.stlouisfed.org/publications/review/13/09/Elliott.pdf.

Elliott, William; Song, Hyun-a and Nam, IlSung. "Small-Dollar Children's Savings Accounts and Children's College Outcomes." Children and Youth Services Review, March 2013, 35(3), pp. 572-85.

Freedman, David A. and Berk, Richard A. "Weighting Regressions by Propensity Scores." Evaluation Review, August 2008, 32(4), pp. 392-409.

Friedline, Terri. "Predicting Children's Savings: The Role of Parents' Savings for Transferring Financial Advantage and Opportunities for Financial Inclusion." Children and Youth Services Review, January 2012, 34(1), pp. 144-54.

Friedline, Terri and Elliott, William. “Connections with Banking Institutions and Diverse Asset Portfolios in Young Adulthood: Children as Potential Future Investors." Children and Youth Services Review, June 2013, 35(6), pp. 994-1006.

Fry, Richard. "A Record One-in-Five Households Now Owe Student Loan Debt." Washington, DC: Pew Research Center, 2012;

http://www.pewsocialtrends.org/2012/09/26/a-record-one-in-five-households-now-owe-student-loan-debt/.

Guo, Shenyang Y.; Barth, Richard P. and Gibbons, Claire. "Propensity Score Matching Strategies for Evaluating Substance Abuse Services for Child Welfare Clients." Children and Youth Services Review, April 2006, 28(4), pp. 357-83; doi:10.1016/j.childyouth.2005.04.012.

Guo, Shenyang Y. and Fraser, Mark W. Propensity Score Analysis: Statistical Methods and Applications. Los Angeles: Sage, 2010.

Health Care and Education Reconciliation Act. 111 U.S.C. § PL 111-152 (2010).

Heller, Donald E. "Student Price Response in Higher Education: An Update to Leslie and Brinkman." Journal of Higher Education, November-December 1997, 68(6), pp. 624-59.

Heller, Donald E. "The Impact of Student Loans on College Access," in Sandy Baum, Michael McPherson, and Patricia Steele, eds., The Effectiveness of Student Aid Policies: What the Research Tells Us. New York: College Board, 2008, pp. 39-68;

https://professionals.collegeboard.com/profdownload/rethinking-stu-aid-effectiveness-of-stu-aid-policies.pdf.

Hiltonsmith, Robert. “Defusing the Student Loan Debt Bomb." Presentation at the University of Kansas, Lawrence, KS, November 7, 2013.

Hu, Souping and St. John, Edward P. “Student Persistence in a Public Higher Education System: Understanding Racial and Ethnic Differences." Journal of Higher Education, May-June 2001, 72(3), pp. 265-86.

Huelsman, Mark. "Enhancing Tax Credits to Encourage Saving for Higher Education: Advancing the American Opportunity Tax Credit and Reforming the Saver's Credit." Washington, DC: New America Foundation, November 2010; http://www.newamerica.net/sites/newamerica.net/files/policydocs/Enhancing_Tax_Credits_to_ Encourage_Saving_for_Higher_Education.pdf.

Johnson, Jean and Rochkind, Jon. "With Their Whole Lives Ahead of Them: Myths and Realities About Why So Many Students Fail to Finish College." New York: Public Agenda, 2013; http://www.publicagenda.org/files/theirwholelivesaheadofthem.pdf.

Kim, Dongbin. "The Effect of Loans on Students' Degree Attainment." Harvard Educational Review, Spring 2007, 77(1), pp. 64-100.

Lee, Donghoon. "Household Debt and Credit: Student Debt." Federal Reserve Bank of New York; February 28, 2013; http://www.newyorkfed.org/newsevents/mediaadvisory/2013/Lee022813.pdf.

Leslie, Larry L. and Brinkman, Paul T. The Economic Value of Higher Education. New York: American Council on Education, Collier Macmillan, 1988.

Loke, Vernon and Sherraden, Michael. “Building Assets from Birth: A Global Comparison of Child Development Account Policies." International Journal of Social Welfare, April 2009, 18(2), 119-29.

Marin, P. "Merit Scholarships and the Outlook for Equal Opportunity in Higher Education," in Donald E. Heller and Patricia Marin, eds., Who Should We Help? The Negative Social Consequences of Merit Scholarships. Cambridge, MA: The Civil Rights Project at Harvard University, 2002, pp. 111-16. 
Mason, Lisa Reyes; Nam, Yunju; Clancy, Margaret; Loke, Vernon and Kim, Youngmi. "SEED Account Monitoring Research: Participants, Savings, and Accumulation." Center for Social Development, Washington University in St. Louis, March 2009; http://csd.wustl.edu/Publications/Documents/RP09-05.pdf.

McPherson, Michael S. and Schapiro, Morton Owen. The Student Aid Game: Meeting Need and Rewarding Talent in American Higher Education. Princeton, NJ: Princeton University Press, 1999.

Miller, Ben. "The Student Debt Review: Analyzing the State of Undergraduate Student Borrowing." New America Education Policy Program Policy Brief, February 2014; http://education.newamerica.net/sites/newamerica.net/files/policydocs/TheStudentDebtReview_2_18_14.pdf.

Newville, David. “The Potential of Inclusive 529 College Savings Plans." Washington, DC: The New America Foundation, May 2010.; http://newamerica.net/publications/policy/the_potential_of_inclusive_529_college_savings_plans.

Paulsen, Michael B. and St. John, Edward P."Social Class and College Costs: Examining the Financial Nexus Between College Choice and Persistence." Journal of Higher Education, March-April 2002, 73(2), pp. 189-236.

Perna, Laura Walker. "Differences in the Decision to Attend College among African Americans, Hispanics, and Whites." Journal of Higher Education, March-April 2000, 71(2), pp. 117-41.

Raudenbush, Stephen W. and Bryk, Anthony S. Hierarchical Linear Models: Applications and Data Analysis Methods. Second Edition. Thousand Oaks, CA: Sage Publications, 2002.

Rosenbaum, Paul R. Observational Studies. Second Edition. New York: Springer-Verlag, 2002.

Rosenbaum, Paul. R. "Observational Study," in Brian S. Everitt and David C. Howell, eds., Encyclopedia of Statistics in Behavioral Science. Hoboken, NJ: John Wiley and Sons, 2005.

Rosenbaum, Paul R. and Rubin, Donald B. “The Bias Due to Incomplete Matching." Biometrics, March 1985, 41(1), pp. 103-16.

Sallie Mae. “How America Saves for College 2013: Sallie Mae's National Study of Parents with Children under Age 18 Conducted by Ipsos Public Affairs." Newark, DE: Sallie Mae, 2013; http://news.salliemae.com/sites/salliemae. newshq.businesswire.com/files/publication/file/HowAmericaSaves_Report2013_1.pdf.

Urahn, Susan K.; Currier, Erin; Wechsler, Laura; Wilson, Denise and Colbert, Daniel. “Pursuing the American Dream: Economic Mobility Across Generations." Washington, DC: Pew Charitable Trusts, July 2012; http://www.pewtrusts.org/ /media/legacy/uploadedfiles/pcs_assets/2012/PursuingAmericanDreampdf.pdf.

U.S. Department of Education. "Race to the Top: College Affordability and Completion. Fiscal Year 2013 Budget Request." 2013; http://www2.ed.gov/about/overview/budget/budget13/justifications/t-rtt.pdf.

Woo, Jennie H. and Choy, Susan P. “Merit Aid for Undergraduates: Trends from 1995-96 to 2007-08," in Thomas Weko, ed., Stats in Brief (NCES 2012-160). Washington, DC: National Center for Education Statistics, October 2011; http://nces.ed.gov/pubs2012/2012160.pdf.

Zhan, Min and Sherraden, Michael. "Assets and Liabilities, Educational Expectations, and Children's College Degree Attainment." Children and Youth Services Review, June 2011, 33(6), pp. 846-54; http://csd.wustl.edu/Publications/Documents/WP09-60.pdf. 
